\title{
Arachidonic acid and docosahexaenoic acid are increased in human colorectal cancer
}

\author{
J P Neoptolemos, D Husband, C Imray, S Rowley, N Lawson
}

Department of Surgery, Dudley Road Hospital, Birmingham

J P Neoptolemos

C Imray

$S$ Rowley

Department of Clinical Chemistry, East

Birmingham Hospital,

Birmingham

D Husband

N Lawson

Correspondence to:

Mr J P Neoptolemos, Academic Department of Hospital, Dudley Road Birming Dudley Road

Accepted for publication 14 May 1990 Surgery, Dudley Road

\begin{abstract}
Increased arachidonic acid concentrations in experimental rodent colonic cancer have been described recently. In humans, a reduced erythrocyte stearic acid to oleic acid ratio has been reported in patients with colorectal cancer and it has been proposed that similar changes exist in the cancer tissue. The long chain fatty acids in the cancers of 15 patients with colorectal cancer were measured and compared with values in the unaffected mucosa. The values were expressed as mean (SD) $\mathrm{mg}$ fatty acid/g tissue and compared by analysis of variance. In the cancer tissue arachidonic acid was increased $(0.703(0.109)$ $\mathrm{mg} / \mathrm{g} v 0.603(0.127) \mathrm{mg} / \mathrm{g}, \mathrm{p}<0.05)$ as was docosahexaenoic acid $(0.211(0.066) \mathrm{mg} / \mathrm{g} v$ $0.148(0.039) \mathrm{mg} / \mathrm{g}, \mathrm{p}<0.001)$. In contrast, the stearic acid to oleic acid ratio in the cancer tissue was increased rather than decreased, as previously suggested $(0.36(0.05) v 0.29(0.7)$, $\mathbf{p}<0.01)$. Increased arachidonic acid and docosahexaenoic acid concentrations may be related to reduced lipid peroxidation, which is a feature of rapidly growing cells. Alternatively, the increased arachidonic acid values could be due to enhanced desaturase activity upon linoleic and linolenic acid, leading perhaps to increased formation of prostaglandins and other lipoxygenase products.
\end{abstract}

Colorectal cancer now represents the second commonest cause of death from cancer in Western countries and is strongly associated with a high fat intake, especially from animal sources. ${ }^{12}$ It has been shown experimentally in rodents that a diet high in saturated fat $(20 \%)$ strongly promotes the formation of colorectal tumours induced by chemical carcinogens

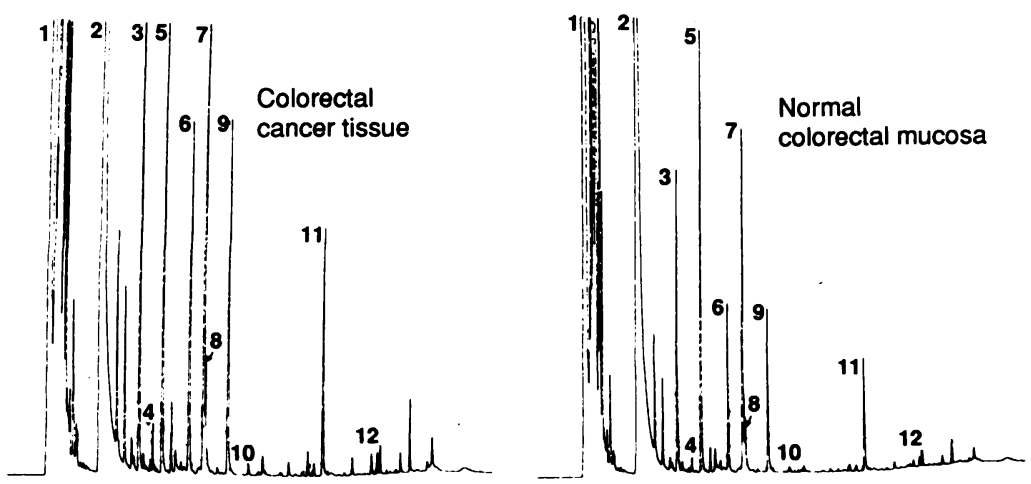

Chromatographs of human colorectal cancer tissue compared with unaffected mucosa. The peaks are as follows: $1=$ solvent front, $2=$ butylated hydroxytoluene, $3=$ palmitic acid, $4=$ palmitoleic acid, $5=$ margaric acid (internal standard), $6=$ stearic acid, $7=$ oleic acid, $8=$ cis-vaccenic acid, $9=$ linoleic acid, $10=$ alpha-linolenic acid, $11=$ arachidonic acid, and $12=$ docosahexaenoic acid. compared with a low saturated fat $(5 \%)$ diet. $^{3-7}$ Analysis of cancer cell membrane fatty acids has shown a significant increase in the concentration of arachidonic acid compared with that in nonmalignant mucosa in azoxymethane induced rodent colorectal cancer, irrespective of the amount or source of dietary fat. ${ }^{589}$

The latter observation may be of direct relevance to carcinogenesis, as arachidonic acid is the precursor of putative tumour promoting series 2 prostaglandins, and in particular of prostaglandin $\mathrm{E}_{2}\left(\mathrm{PGE}_{2}\right) .^{10}$ Indeed, reduced experimental tumour growth has been related to inhibition of tumour $\mathrm{PGE}_{2}$ synthesis by indomethacin $^{11}$ and the methyl ester of eicosapentaenoic acid. ${ }^{12}$

There has also been some recent interest in the ratio of stearic acid to oleic acid in the red cell membranes of patients with colorectal cancer. In 1985 , Wood et $a l^{13}$ reported a reduced erythrocyte ratio in patients with colorectal cancer which was related to Dukes' staging, radical resection, and subsequent recurrence. ${ }^{131+}$ Moreover, a desaturating factor, supposedly showing delta-9-desaturase activity, which converts stearic acid to oleic acid, was isolated from the tissue, serum, and urine of cancer patients. ${ }^{1516}$ These authors argued that this desaturation was taking place in the cancer and could be used in cancer treatment. ${ }^{17}$

Despite the increasing interest in experimental systems, there are no published data of human colorectal cancer tissue. Therefore, we undertook the present study of colorectal tissue long chain fatty acids from patients undergoing elective surgery.

\section{Patients and methods}

\section{PATIENTS}

The study group consisted of 15 consecutive patients with colorectal cancer who presented to one surgeon (JPN) for elective surgery at Dudley Road Hospital, Birmingham. There were 10 women and five men with a mean age of 73.3 (range 58-88) years. Those patients presenting with anaemia, bowel obstruction, or weight loss of more than $10 \%$ were excluded. None of the patients were receiving chemotherapy or had received radiotherapy. All were omnivores on a free range diet. The sites of the cancers were rectum $(n=11)$, caecum $(n=2)$, and sigmoid colon $(n=2)$. The cancer staging according to Dukes was: Dukes' A, one; Dukes' B, nine; and Dukes' $\mathrm{C}$, five (two also with liver metastasis). Three of the tumours were well differentiated, nine were moderately well differentiated, and three were poorly differentiated. 
TISSUE

Immediately after resection the bowel was divided longitudinally to reveal the bowel lumen. Small slices of the cancer were obtained by sharp dissection and frozen in liquid nitrogen. The mucosa furthest away from the cancer was dissected off the muscle and frozen similarly. The tissue was stored in liquid nitrogen until analysis.

\section{SOURCES OF MATERIALS}

Unless otherwise stated, all chemicals and reagents were of analar grade and were obtained from the Sigma Chemical Company Ltd, Poole, Dorset, UK.

\section{FATTY ACID ANALYSIS}

Fatty acids were analysed by a modification of a previously described method. ${ }^{18}$ After thawing, aliquots of tissue were weighed (200-1000 mg) and homogenised on ice in $10 \mathrm{ml}$ of $0.1 \mathrm{mmol} / 1$ Tris $\mathrm{HCl}$ buffer ( $\mathrm{pH} 8.9$ ) in a Polytron homogeniser (setting $=6$ ) for 30 seconds. A $2 \mathrm{ml}$ aliquot of tissue homogenate was placed in a screw topped glass tube to which was added $5 \mathrm{ml}$ of methanol $/ 6 \mathrm{~mol} / 1 \mathrm{HCl}$ ( $5: 1$ by volume), and $0.2 \mathrm{ml}$ of methanol containing $20 \mathrm{~g} / \mathrm{l}$ of the antioxidant butylated hydroxytoluene, and the internal standard, margaric acid (17:0, $1 \mathrm{~g} / \mathrm{l})$. The fatty acids were transesterified by incubating at $90^{\circ} \mathrm{C}$ under nitrogen for four hours. After cooling, the fatty acid methyl esters were extracted into $8 \mathrm{ml}$ of hexane and washed with saturated $\mathrm{NaCl}$ solution. The samples were dried over anhydrous sodium sulphate and evaporated to dryness under nitrogen at $37^{\circ} \mathrm{C}$. The samples were then disolved in $0.2 \mathrm{ml}$ of hexane and sealed in brown glass ampoules. They were stored at $-20^{\circ} \mathrm{C}$ and analysed within one week. Fatty acid standards were prepared as described previously. ${ }^{18}$

Fatty acid methyl esters were analysed by gas liquid chromatography using a Pye Unicam Series 304 chromatograph (Philips Scientific, Cambridge, UK) and a fused silica tube capillary column (50 m WCOT CPSil 88, 0.33 mm internal diameter, Chrompak UK Ltd) with flame ionisation detection. The gases used were helium as the carrier gas $(2.7$ bar; flow rate $0.483 \mathrm{ml}$ minute) with air and hydrogen for the detector. The injection temperature was set at $270^{\circ} \mathrm{C}$ for each run and the oven temperature was initially ramped at $2^{\circ} \mathrm{C} /$ minute from $150^{\circ} \mathrm{C}$ to $200^{\circ} \mathrm{C}$, then ramped at $5^{\circ} \mathrm{C} /$ minute between $200^{\circ} \mathrm{C}$ and $240^{\circ} \mathrm{C}$, and finally held for six minutes. Detection was at $300^{\circ} \mathrm{C}$.

The fatty acids were identified from their retention times and based on the use of authentic fatty acid methyl ester standards. The coefficients of variation of the nine major fatty acid methyl esters of interest ranged from $0.9 \%$ to $3.6 \%$ for within batch variation and from $2.9 \%$ to $9 \cdot 1 \%$ for inter batch variation. ${ }^{18}$

The results were expressed in absolute units that is as mg fatty acid per $\mathrm{g}$ weight wet tissue, and were based on the mean of at least two traces. Relative values (\%) are also given for comparison with other studies.

\section{STATISTICAL ANALYSIS}

The data were entered into the University of Birmingham mainframe computer (IBM3090) and analysed by analysis of variance. The significance of the $F$ ratios was determined from tables (Documenta-Geigy). Significance was taken as $\mathrm{p}<0.05$.

\section{Results}

A typical chromatogram is shown in the Figure. The total fatty acid content in mucosa was mean (SD) $6.271(1.515) \mathrm{mg} / \mathrm{g}$ compared with $6.581(1.411) \mathrm{mg} / \mathrm{g}$ in the cancer (NS). The comparison of individual fatty acids, along with $95 \%$ confidence intervals of the values, is shown in the Table. The stearic acid:oleic acid ratios were mean (SD) $0.29(0.07)$ in the mucosa compared with $0.36(0.05)$ in the cancer tissue $(p<0.01)$. The total polyunsaturated fatty acids in mucosa were $1.734(0.334) \mathrm{mg} / \mathrm{g}$ compared with $1.905(0.390) \mathrm{mg} / \mathrm{g}$ in the cancer (NS); similarly there was no significant difference for total unsaturated fatty acids -4.22 $(1.09) \mathrm{mg} / \mathrm{g} \vee 4.361(0.0972) \mathrm{mg} / \mathrm{g}$ respectively.

Comparison of fatty acids in normal mucosa compared with those in cancer $(n=15$, paired samples). Values are mean $(S D)(95 \%$ confidence intervals)

\begin{tabular}{|c|c|c|c|c|c|}
\hline \multirow[t]{2}{*}{ Fatty acid } & & \multicolumn{2}{|l|}{ Mucosa } & \multicolumn{2}{|l|}{ Cancer } \\
\hline & & $\begin{array}{l}\text { Fatty acid } \\
\text { (mg/g tissue) }\end{array}$ & $\%$ & $\begin{array}{l}\text { Fatty acid } \\
\text { (mg/g tissue) }\end{array}$ & $\%$ \\
\hline $16: 0$ & Palmitic acid & $\begin{array}{r}1.472(0.374) \\
(1.265,1.680)\end{array}$ & $23 \cdot 3(1 \cdot 7)$ & $\begin{array}{r}1.568(0.331) \\
(1.384,1.753)\end{array}$ & $22 \cdot 0(5 \cdot 7)$ \\
\hline $16: 1(n-7)$ & Palmitoleic acid & $\begin{array}{r}0.142(0.075) \\
(0.100,0.184)\end{array}$ & $2 \cdot 1(0 \cdot 8)$ & $\begin{array}{r}0.171(0.086) \\
(0.123,0.219)\end{array}$ & $2 \cdot 8(1 \cdot 3)$ \\
\hline 18:0 & Stearic acid & $\begin{array}{r}0.577(0.120) \\
(0.511,0.644)\end{array}$ & $9 \cdot 4(1 \cdot 8)$ & $\begin{array}{l}0.695(0.134)^{\star} \\
(0.621,0.769)\end{array}$ & $10 \cdot 6(1 \cdot 1)$ \\
\hline $18: 1(n-9)$ & Oleic acid & $\begin{array}{r}2.080(0.608) \\
(1.743,2.417)\end{array}$ & $32 \cdot 8(3 \cdot 6)$ & $\begin{array}{r}1.954(0.504) \\
(1.674,2.233)\end{array}$ & $29 \cdot 6(2 \cdot 6)$ \\
\hline $18: 1(n-7)$ & Cis-vaccenic acid & $\begin{array}{r}0.264(0.164) \\
(0.174,0.355)\end{array}$ & $4 \cdot 0(1 \cdot 6)$ & $\begin{array}{r}0.314(0.147) \\
(0.232,0.395)\end{array}$ & $4 \cdot 4(1 \cdot 4)$ \\
\hline $18: 2(n-6)$ & Linoleic acid & $\begin{array}{r}0.959(0.262) \\
(0.814,1.104)\end{array}$ & $15 \cdot 4(2 \cdot 8)$ & $\begin{array}{r}0.991(0.283) \\
(0.834,1.148)\end{array}$ & $14 \cdot 8(2 \cdot 4)$ \\
\hline $18: 3(n-3)$ & Alpha linolenic acid & $\begin{array}{r}0.026(0.018) \\
(0.016,0.035)\end{array}$ & $0.4(0.3)$ & $\begin{array}{c}0.017(0.012) \\
(0.010,0.0236)\end{array}$ & $0 \cdot 3(0 \cdot 2)$ \\
\hline $20: 4(n-6)$ & Arachidonic acid & $\begin{array}{r}0.603(0.127) \\
(0.533,0.673)\end{array}$ & $9 \cdot 9(2 \cdot 1)$ & $\begin{array}{c}0.703(0.109) \\
(0.642,0.763)\end{array}$ & $10.9(1 \cdot 7)$ \\
\hline $22: 6(n-3)$ & Decosahexaenoic acid & $\begin{array}{r}0 \cdot 148(0.039) \\
(0 \cdot 126,0 \cdot 169)\end{array}$ & $2 \cdot 4(0 \cdot 7)$ & $\begin{array}{l}0.211(0.066)^{\star \star} \\
(0.174,0.248)\end{array}$ & $3 \cdot 1(0 \cdot 9)$ \\
\hline
\end{tabular}




\section{Discussion}

To our knowledge, this is the first study to show compositional changes of fatty acids in human colorectal cancer. The fatty acid profile of the unaffected mucosa was similar to that of control subjects in a study of inflammatory bowel disease. ${ }^{19}$ Also, the rectal mucosa fatty acid profile of patients undergoing surgery for haemorrhoidectomy was found not to differ from the normal rectal mucosa from patients with colorectal cancer ascertained by packed column chromatography, thereby excluding a mucosal lipid field change in these patients. ${ }^{9}$ Thus, the use of non-malignant mucosal fatty acids as a comparison for cancer tissue fatty acids is valid. Moreover, as diet may have subtle influences on colonic mucosal fatty acid profiles of both rodents 58122021 and humans (rather than age or sex), ${ }^{9}$ such a comparison will provide more precise information relating to cancer tissue per se.

Consistent with experimental data, ${ }^{59}$ an increased arachidonic acid concentration was found in the cancer tissue. Given that this is the precursor of series 2 prostaglandins, it is relevant that $\mathrm{PGE}_{2}$ has been shown to be increased in human colorectal cancer tissue. ${ }^{22}$ Evidence suggests that $\mathrm{PGE}_{2}$ in particular is a potent tumour promoter..$^{10}$ Not only has chemically induced colon carcinogenesis in rodents been significantly reduced by inhibitors of series 2 prostaglandins, ${ }^{112}{ }^{23}$ but the growth of the human colonic cell lines COLO-320 and HT-29 implanted into nude mice is also reduced by dietary n-3 lipids. ${ }^{24} 25$ Furthermore, the reduced tumour growth of colonic tumours is related to reduced tumour content of arachidonic acid by dietary n-3 lipids. ${ }^{12}{ }^{25}$ Nevertheless, arachidonic acid and prostaglandins in colorectal cancer tissue obtained from patients remains to be established. In particular, it will be important to determine the activity of the cyclo-oxygenase systems involved as this is likely to be a more important determinant of prostaglandin synthesis than substrate availability.

In contrast to the hypothesis of Wood, Habib et $a l^{13-17}$ the stearic acid:oleic acid ratio was not reduced but increased. This is perhaps not surprising given that this ratio in red cells was not found to be significantly different between patients with colorectal cancer and age and sex matched control subjects in two separate studies. ${ }^{2627}$ Although evidence was produced to support the reduced stearic acid:oleic acid red cell ratio in experimental colon cancer,,$^{178}$ Nicholson' has shown that dietary influences predominate. Moreover, adipose tissue linoleic acid was inversely correlated with mucosal oleic acid' confirming the potent inhibitory effect of linoleic acid (only available from the diet) on delta-9-desaturase activity. ${ }^{29}$

An unexpected finding was the significant increase in docosahexaenoic acid in the cancer tissue. An important feature of rapidly growing cells is that they generally exhibit decreased lipid peroxidation while slowly dividing cells show increased values. ${ }^{30-32}$ In particular, after partial hepatic resection, cycles of cell division are directly linked with considerably reduced concentrations of lipid peroxides. ${ }^{30-32}$ Conversely, the growth of cancer cells in vitro can be inhibited by stimulating lipid peroxidation. ${ }^{33-35}$ Moreover, a number of cancer cell lines have been shown to lack important antioxidant systems. ${ }^{36}$ The source of lipid peroxides is long chain polyunsaturated fatty acids, particularly arachidonic acid and docosahexaenoic acid. Increased tissue concentrations of these two fatty acids can be used as an important measure of reduced lipid peroxidation. ${ }^{37}$ Therefore, the findings in this study are consistent with such a process taking place.

The basis for the increase in arachidonic acid values in the cancer tissue remains to be established. This increase could be due to increased conversion because of enhanced desaturase activity upon the precursors linoleic acid and bis homo-gamma-linolenic acid. ${ }^{38}$ Alternatively, there may be decreased utilisation of arachidonic acid to form lipid peroxides or prostaglandins and leukotrienes. Clearly a combination of these processes may be occurring: thus it is possible that there is both increased delta-6-desaturase activity and prostanoid production along with decreased lipid peroxidation.

In conclusion, differences in the fatty acid content of human colorectal cancer tissue have been described. This study therefore justifies further investigations in order to determine the mechanism involved.

We are grateful to the Department of Medical Illustration and to Mrs Dilys Thomas, Dudley Road Hospital, for the preparation of the illustration and the manuscript. J P Neoptolemos and C Imray are supported by the Cancer Research Campaign

Abstract presented to British Society of Gastroenterology meeting in Warwick, March 1990.

1 Armstrong B, Doll R. Environmental factors and cancer incidence and mortality in different countries, with special reference to dietary practices. Int $\mathcal{F}$ Cancer 1975; 15: 617-31.

2 Nicholson ML, Neoptolemos JP, Clayton HA, Heagerty AM. Diet and colorectal cancer. Int Clin Nutri Rev 1988; 8: 180 97.

3 Bull AW, Soullier BK, Wilson PS, Hayden MT, Nigro ND. Promotion of azoxymethane-induced intestinal cancer by high-fat diet in rats. Cancer Res 1979; 39: 4956-9.

4 Galloway DJ, Jarrett F, Boyle P, et al. Morphological and cell kinetic effects of dietary manipulation during colorectal carcinogenesis. Gut 1987; 28: 754-63.

5 Nicholson ML, Neoptolemos JP, Clayton HA, Talbot IC, Bells PRF. Increased arachidonic acid in experimental Bells PRF. Increased arachidonic acid in experiment
colorectal tumours (Abstract). Br F Surg 1989; 76: 1337.

6 Nigro ND, Singh DV, Campbell RL, Pak MS. Effect of dietary beef fat on intestinal tumour formation by azoxymethane in rats. $\mathcal{F N C I} 1975 ; 54: 439-42$

7 Reddy BS, Watanabe K, Weisburger JH. Effects of high-fat diet on colon carcinogenesis in F344 rats treated with 1 , 2-dimethylhydrazine, methylazoymethanol acetate or methylnitrosourea. Cancer Res 1977; 37: 4156-9.

8 Nicholson ML, Neoptolemos JP, Clayton HA, Talbot IC, Bell PRF. Fatty acids in experimental colorectal carcinogenesis (Abstract). Br $\mathcal{F}$ Surg 1990; 77704

9 Nicholson ML. Fatty acids in colorectal cancer. [MD Thesis]. University of Leicester, 1989.

10 Goodwin JS, Ceuppens J. Regulation of the immune response by prostaglandins. F Clin Immunol 1983; 3: 295-315

11 Narisawa T, Sato M, Sano M, et al. Prevention of colon polyposis and carcinomas by right hemicolectomy and polyposis and carcinomas by right hemicolectomy and

12 Minoura T, Takata T, Sakaguchi $M$, et al. Effects of dietary eicosapentaenoic acid on azoxymethane-induced colon carcinogenesis in rats. Cancer Res 1988; 48: 4790-4.

13 Wood CB, Habib NA, Thompson A, et al. Increase of oleic acid in erythrocytes associated with malignancies. $\mathrm{Br} \mathrm{Med} \mathcal{F}$ 1985; 291: 163-5.

14 Habib AN, Hershman MJ, Carter P, Apostolov K, Williamson RCN, Wood CB. Erythrocyte stearic acid desaturation in patients with colorectal carcinoma. Gut 1986; 27: A599.

15 Habib NA, Hersham MJ, Smadja C, Wood CB, Apostolov K, Barker W. Desaturation of cell membrane fatty acids by urine from patients with cancer. Surg Res Comm 1987; 1: $111-4$.

16 Habib NA, Wood CB, Apostolov K, et al. A desaturation producing factor in the tissue, blood and urine of cancer patients. Cancer Detect Prev 1987; 10: 57-61. 
17 Habib NA, Wood CB, Apostolov K, et al. Stearic acid and carcinogenesis. Br $\mathcal{F}$ Cancer 1987; 56: 455-8.

18 Lawson N, Husband D, McGuigan J, Watson DCT, Collins FC, Pandov HP. Increased levels of vaccenic acid in bronchogenic carcinoma tissue. Ann Clin Biochem 1989; 26 : 125-31.

19 Nishida T, Miwa H, Shigematsu A, Yamamoto M, Ida M, Fujishimo $M$. Increased arachidonic composition of phospholipids in colonic mucosa from patients with active pholipids in colonic mucosa from patie

20 Brasitus TA, Davidson ND, Schacter D. Variations in dietary triacylglycerol saturation alter the lipid composition and fluidity of rat intestinal plasma membranes. Biochim Biophys Acta 1985; 812: 460-72.

21 Sakaguchi M, Hiramatsu Y, Takada $\mathrm{H}$, et al. Effects of dietary unsaturated and saturated fats on azoxymethane-induced colon carcinogenesis in rats. Cancer Res 1984; 44: 1472-7.

22 Bennett A, Del Tacca M, Stamford IF, Zebro T. Prostaglandins extracted from tumors of human large bowel. $\mathrm{Br} \mathcal{J}$ Cancer 1977; 35: 881-4.

23 Reddy BS, Sugie S. Effect of different levels of omega-3 and omega- 6 fatty acids on azoxymethane-induced colon

24 Sakaguchi M, Rowley S, Kane N, et al. Modulation of colon cancer fatty acids by dietary $\mathrm{n}-3$ lipids results in tumour cancer fatty acids by dietary $\mathrm{n}-3$ lipids results in tumo
growth suppression (Abstract). Br $\mathcal{Y}$ Surg 1989; 76: 1337 .

25 Sakaguchi M, Imray C, Rowley S, et al. Relationship of tissue and tumour fatty acids to dietary fat in experimental and tumour fatty acids to dietary fat in experin
colorectal cancer (Abstract). Gut 1989; 30: A1449.

26 Neoptolemos JP, Clayton H, Heagerty AM, et al. Dietary fat in relation to fatty acid composition of red cells and adipose tissue in colorectal cancer. Br 7 Cancer 1988; 58: 575-9.

27 Neoptolemos JP, Thomas BS. Red cell membrane fatty acid profiles in colorectal cancer using tube capillary gas chromatography. Ann Clin Biochem 1990; 29: 38-43.
28 Habib NA, Hershman MJ, Salem R, Apostolov K, Wood CB. Increased erythrocyte stearic acid desaturation in rats with chemically induced colorectal carcinomas. Int $\mathcal{f}$ Colorectal Dis 1987; 2: 12-4.

29 Jeffcoat R, Roberts PA, James AT. Stearoly-COA desaturase: a control enzyme in hepatic lipogenesis. Eur F Biochem 1979; 101: 447-53.

30 Ohnishi T. Lipid peroxidase formation and phospholipid in normal and tumour tissues. Gann 1958; 49: 233-48.

31 Wolfson N, Wilbur KM, Bernheim F. Lipid peroxide formation in regenerating rat liver. Exp Cell Res 1956; 10: formation

32 Cheeseman K, Collins M, Proudfoot K, et al. Studies on lipid peroxidation in normal and tumour tissues. Biochem $\mathcal{F}$ 1956; 235: 507-14

33 Begin ME, Das UN. Selected fatty acids as possible intermediates for selective cytotoxic activity of anticancer agents involving oxygen radicals. Anticancer Res 1986; 6: 291-6.

34 Begin ME, Ells G, Das UN, Horrobin DF. Differential killing of human carcinoma cells supplemented with $n-3$ and $n-6$ polyunsaturated fatty acids. INCI 1986; 77: 1053-62.

35 Begin ME, Ells G, Horrobin DF. Polyunsaturated fatty acidinduced cytotoxicity against tumor cells and its relationship induced cytotoxicity against tumor cells and its

36 Tisdale MJ, Mahmoud MB. Activities of free radical metabolizing enzymes in tumours. Br $\mathcal{F}$ Cancer 1983; 47: 809-12.

37 Mead JF, Alfin-Slater RB, Howton DR, Popjak G. Peroxidation of fatty acids. In: Lipids, Chemistry, Biochemistry, and Nutrition. New York: Plenum Press, 1986: 83-99.

38 Jeffcoat $R$, James AT. The regulation of desaturation and elongation of fatty acids in mammals. In: Numbar S (ed) Fatty acid metabolism and its regulation. Amsterdam: Elsevier Science Publishers BV, 1984: 85-112. 